\title{
THE ANALYSIS OF STRUCTURE SHIFT \\ IN THE ENGLISH TRANSLATION OF THESIS ABSTRACTS FOUND AT TEACHER TRAINING AND EDUCATION FACULTY HALU OLEO UNIVERSITY
}

\author{
Iwan Supriyatno \\ English Language Education Department \\ Halu Oleo University \\ Iwansupriyatno88@gmail.com \\ Alimin \\ Halu Oleo University \\ Rohmana \\ Halu Oleo University
}

\begin{abstract}
This study is an attempt to contribute in the study of translation shift. The goal is to find out and describe the structure shift that occurs in Indonesian-English translation. This study also analized the accuracy of translations that contain structure shifts. The analysis was specifically directed to the thesis abstracts and their English translation version that taken from the library of Teacher Training and Education Faculty, Halu Oleo University. This study employed qualitative design. The total abstracts involved as source of data in this study were 2 abstracts that came from one study program, that is, Early-childhood Education. The analysis of the structure shift was based on the theory of Catford (1965). The result revealed that the structure shifts do exist in the translation of the thesis abstracts. Specifically, there are 10 structure shifts found in this study. Furthermore from these data, 4 of them are considered inaccurate translation; 5 are considered accurate translation; and only 1 is considered very accurate translation. This study concluded that the translator"s comprehension about the target language system is highly required in order to produce an accurate translation. This study also suggests that the translation shifts shoud be included as one topic to be discussed in translation class.
\end{abstract}

Keywords: Structure shift, Accuracy, Thesis Abstract

\section{Introduction}

Translation nowadays is a very important phenomenon. However, translation is never done without its difficulties. Nida and Taber said that "Translating consists in reproducing the receptor language, the closest natural 
equivalent of the source-language message, firstly in terms of language and secondly in terms of style" (1982: 12). It means that a translator has to understand the context of communication and the cultural context of the source and target text. Moreover, a translator has to put into account the author writing style when transferring a text from one language into another. It is also a fact that languages have their own characteristics which differ to one another. Consequently, this makes translating texts even more difficult. Therefore, to get a quality translation, translators may refer to different strategies. One of the strategies translator may refer is a linguistic-based approach proposed as translation shifts by Catford (1965).

In Catford ${ }^{\text {ee }} \mathrm{s}$ term, there are two main types of translation shifts namely level shifts and category shifts. Level shifts occur when the Source Language (SL) item at one linguistic level (e.g. grammar) has a Target Language (TL) equivalent at a different level (e.g. lexis) (Catford, 1965: 73). Meanwhile, Category shifts are departure from formal correspondence in translation (Catford, 1965: 76). It is divided into four sub-types: Structure-shifts, class-shifts, Unit-shifts, Intra-system shifts (Catford, 1965).

Shifts seem to occur in every translation work. Cyrus (2006: 1240) says that translations contain a lot of shifts because they differ in many ways from their source text, and straightforward correspondences are mostly exception. With huge number of shifts found in the translation work, it should not be seen as problems. Instead, shift in translation must be considered as an important part in the translation process. This assumption is supported by Farrokh (2011) who states that shifts could minimize the inevitable loss of meaning when rendering a text from one language into another language. This strategy, then, provides benefit of helping translators to translate easier and produce a better product. Therefore, with the benefits it offers, shift has become a very useful tool for translator. However, one should be extremely careful when shifting in translation.

It has been widely known that to make a good translation, the translation has to be accurate (Foster, 2016). It means that the message should be properly transfered to the the Target Language (TL). Now, with the presence of shifts or changes in translation, the translation may or may not become accurate. It is because when a translator deviates too far from the original text, it may change or 
corrupt the transfer of the message from SL to TL. Accordingly, when a translator strictly follows the structure of SL, the result of translation may not become natural and eventually the message is not transfered properly. Therefore, when shifting, a translator should be very careful not to change the message instead. One has to keep in mind that the idea of shift is to help the process of translation, not to ruin it.

With the benefits it offers, translation shift has become a popular topic of interest for scholars in the field of translation. Recently, many scholars have put their attention toward translation shift. They have conducted studies to investigate and describe the term shift in translation. However, many of the studies put their focus on literary texts, and only few which focus on non-literary translation. The present study considers the need to take into account the non-literary text since this kind of text is directly related to science and education field. This study attempted to analyze the occurrence of translation shift in the translation of thesis abstract.

Abstract is universal in an academic writing and every academic writing must contain an abstract. According to Kies (2005), an abstract is a summary that highlights the major points of the works and outlines the significant details. Abstract is an important part of a thesis because it represents the whole content of the thesis.

This study is inspired by the fact that translation shifts are unavoidable in translation and they help translators to maintain the equivalence of meaning. The analysis focused on structure shift proposed by Catford. The reason is because Catford mentioned this particular kind of shift as the most common one to occur in translation (Catford, 1965:77). The researcher believes that the result of this study can contribute in the literature of translation shift. It can also be useful for translation class especially at Halu Oleo University since, based on preobservation, this term is still unfamiliar for the translation class at the university. 
Therefore, this study can be used as a reference or study sample in the translation class and prepares the students to be good translators.

\section{Literarture Review}

\section{Translation Shift}

Based on Catford ${ }^{\text {ee }} \mathrm{s}$ definition, shift is a departure from formal correspondence in the process of going from the SL to the TL (Catford, 1965: 73). It is, then, necessary to point out about formal correspondence. According to Catford (1965: 27), "formal correspondence is any TL category which may be said to occupy, as nearly as possible, the „same" place in the economy of the TL as the given SL category occupies in the SL." He gives an example that if we find that two languages operate each with grammatical units at five rank (sentence, clause, word, phrase, morpheme), we can reasonably say that there is a formal correspondence between the two hierarcies of unit in both language (Catford, 1965: 32). Then, we can conclude that a translation shift occurs when a TL is observed as the equivalent translation of the SL but the formal correspondence is absent in the translation.

Shifts can occur either mandatorily or optionally. Mandatory shift means that the action of the translator is dictated by the structural discrepancies between the two language systems involved in this process (Al-Zoubi \& Al-Hassnawi, 2001). Meanwhile, the optional shift means the shifts occurred by the translator personal and stylistic preferences to which he resorts consciously for the purpose of natural and communicative rendition of an SL text into another language (AlZoubi \& Al-Hassnawi, 2001).

There are two types of shift in Catford ${ }^{\text {ee }}$ model. They are level shift and category shift. Level shift, explained by Catford (1965: 73), occurs when SL item at one linguistic level has a TL translation equivalent at a different level. In his book, he further mentions that it is from the level of grammar to lexis or vice versa (Catford, 1965:73). For example:

SL : Budi has stopped smoking

TL : Budi sudah berhenti merokok. 
In the example above, the SL grammatical form „has stopped ie is translated into TL word (lexis) „sudah“" This kind of change, then, is called level shift.

Category shift is a departure from formal correspondence in translation (Catford, 1965: 73). It has been pointed out that shifts occur when formal correspondence is missing in the process of translation. Catford (1965: 27) mentioned that formal correspondence can be established in several categories: unit, structure, class, intra-system. "It is changes of these categories which we refer to as category-shift" (Catford, 1965: 76). In other words, whenever a shift occurs in respect of these categories, it is called category shifts. Therefore, category shifts are divided into four sub-types:

a. Structure shift

Structure shift is to be the most common form of shift and involves mostly a shift in grammatical structure (Catford, 1965: 77). Structure shifts occur when the TL elements of unit are different or they are the same but arranged differently (Catford, 1965: 77). The examples are as follows:

1) SL: Ia mengambil bola itu dari dalam kotak.

TL: The ball was taken out of the box.

2) SL: toko buku

TL: book store

It is obvious that word arrangement in each translation is changed. In (1), the position of the object and the predicate is different between SL and TL. In (2), SL phrase has an initial head while the TL phrase has a final head. The changes of arrangement in the example above are what we refer as a structure shift.

b. Unit shift

A unit is defined as "a stretch of language activity which is the carrier of a pattern of a particular kind" (Catford, 1965: 5). Unit-shift means change of rank that is, departures from formal correspondence in which the translation equivalent of a unit at one rank in the SL is a unit at a different rank in the TL (Catford, 1965: 79). Therefore, a unit shift is a change of grammatical unit.

Machali (2000) states that every language has a pattern or grammatical system that consists of hierarchy of five language units: (1) morpheme; (2) word; 
(3) phrase; (4) clause; (5) sentence. Unit shifts occur when a SL item at one unit is translated with different unit at TL. If the shift occurs from the lower unit to the upper one, it is called upward unit/rank shift, whereas if it goes downward, it is called downward unit/rank shift. The examples are as follows:

(1) SL: gaya tarik bumi

$$
\text { TL: gravity }
$$

(2) SL: kembali

\section{TL: come back}

In the example (1) there is a change from a phrase 'gaya gravitasi bumi' into a word "gravity". So, there is downward rank shift in this translation. Meanwhile, in the example (2) there occurs upward rank shift for a word „kembali' in Indonesia is a textual equivalence with phrase „,come back ${ }^{\text {"e }}$ in English.

\section{c. Class shift}

The class shifts occur when there is a change in the word class in the translation process (Catford, 1965: 78). DeCapura (2008: 27) states that in general, there are eight parts of speech in English. It includes noun, verb, adjective, adverb, preposition, pronoun, conjunction, and determiner. So, when the target text has an item that consists of a word which stands as one of the parts of speech and it is translated as a word which stands as a part of speech different with the target one, it is called class shift. For example:

\section{SL: mahasiswa kedokteran}

TL: medical student

There is class shift because the word 'kedokteran' (noun) is translated into "medical" (adjective).

d. Intra system shift

Intra-system shifts occur when the „SL and TL possess approximately corresponding systems, but where the translation involves selection of a noncorresponding term in the TL system" (Catford, 1965: 80). For example:

1) (SL) sebuah kacamata $=>(\mathrm{TL})$ a pair of glasses 
2) (SL) 8 ekor kucing $=>$ (TL) 8 cats

In example (1), the two phrases express the same item with the same number. However, the phrase is in singular in SL (Indonesian) while it is plural in TL (English). Both languages actually have their own singular and plural form of noun. However, in Indonesian the item (glasses) is seen as one single item while in English it is seen as two pieces of glasses sticked together. That is why the first is singular form and the other is in plural.

In example (2), the case is almost the same. The SL item (kucing) is in singular while the TL item (cats) is in plural. Again, both languages actually have their own singular and plural form of noun. In Indonesian the plural form of „kucing' is „kucing-kucing', while the singular form of „catse in English is „cat". However, in Indonesian, when a noun is initialized by plural marker, the noun has to be in singular form. Therefore, in the example above, eventhough, both phrases express the same number of cat, the SL has to be in singular while the TL is in plural. So, we have intra-system shift in this translation, that is singular to plural.

\section{Previous Studies}

This section provides the review of previous studies regarding the category shift in translation.

Susana (n.d.) conducted a study to analyze the structure shift of locative prepositional phrase and its equivalences in Indonesian. The data of his study were taken from the biography of Steve Jobs. The book was published in English as the source language and in Indonesian as the target language. It is only the structure shift of locative prepositional phrase using preposition „ate, „in „from" was analyzed. The research was done through note taking technique in order to find and collect some data. The main theory used to analyze the structure shift in translation of the biography of Steve Jobs is Translation Shift proposed by Catford (1965). The finding shows that the translation shift in this structure shift affects the process of translating locative prepositional phrase. Loss and gain information occur in the process of translation from source language into target language. 
Herman (2014) conducted a research in order to find out the shifts in movie subtitle of Harry Potter especially for the Harry potter and the Philosopher"s stone Movie Subtitle into Indonesia. Problems discussed in the research: 1) what kinds of category shifts found in the movie of Harry potter and the Philosopher"s stone into Indonesia subtitle? 2) what is the dominant category shift found in the movie of Harry potter and the Philosopher"s stone into Indonesia subtitle? The findings show: 1) all kinds of category shifts found in the subtitle from English into Indonesia, 2) the dominant category shift found in movie subtitle is unit shift.

Hosseini-Massoum and Shahbaiki (2013) conducted a study regarding category shift. Their study intended to find the realization of Catford ${ }^{e e}$ s shifts in the Persian translation of Charles Dickens" "A Tale of Two Cities" by Ebrahim Younesi. The paper analyzed different kinds of category shifts which Catford divides into four subgroups: structure shifts, class shifts, unit shifts and intrasystem shifts in translation. To this end, forty sentences of the first six chapters of the novel were selected randomly and compared with their corresponding parts in the Persian translation. The result of the study shows that among forty sentences that include forty-three shifts, unit shift is the most frequent type of shift. $37.5 \%$ of shifts are unit shifts, $30 \%$ class shifts, $12.5 \%$ structure shifts and $27.5 \%$ intra system shifts. The result also shows that shifts are inevitable in some places in the translation process and this is because of different natures of languages and variations that exist among them, so the translator is forced to deviate from the source text.

Based on the above studies, it is shown that translation shift is inevitable in translation. However, the studies focus their analysis on literary texts and none of them studied the Indonesian-English translation context. The present study attempted to fill this gap. The present study attempted to analize the structure shift that occurs in an academical text. Therefore, the present study analyzed the Indonesian-English translation of thesis abstracts, and tried to see whether these two gaps result in the same findings. 


\section{Methods}

This study employed a descriptive qualitative design which means all the data in this study was analyzed descriptively through sentences. The source of the data in this study was thesis abstracts written in Indonesian and their English translation version taken from the library of Teacher Training And Education Faculty of Halu Oleo University. There were two thesis abstracts chosen as corpus in this study along with their translation versions. They come from Earlychildhood Department and are approved on Mei 2017. This study used „collecting and examining"e method of data collection. According to Yin (2011), collecting data refers to the compiling or accumulating of objects (documents, artifacts, and archival records) related to the study topic. After the thesis abstracts are collected, the researcher examined the sentences to see what types of „category shifts" exist in the translation of the analyzed abstracts. After collecting the data, the researcher analized the data qualitatively.

\section{Findings}

Here are some of the structure shifts found in this study.

\begin{tabular}{|l|l|}
\hline \multicolumn{1}{|c|}{ Source Language } & \multicolumn{1}{c|}{ Target Language } \\
\hline Pada siklus II, persentase & The second cycle teacher teaching \\
ketercapaian aktivitas mengajar guru & activity obtained the percentage of \\
mengalami peningkatan menjadi & $92,86 \%$ or 14 aspects were \\
$92,86 \%$ atau 13 aspek dari 14 aspek & observed by 13 aspect achieved by \\
yang diamati sedangkan persentase & the teacher, while the percentage \\
yang tidak tercapai sebesar 7,l4\% & was not reached by 7,14\% or 1 \\
atau 1 aspek. & aspects. \\
\hline
\end{tabular}

In the SL-TL pair above, it is noticed that the elements of both sentences do not formally correspond. The SL sentence is formed with adverbial (A) + Subject $(\mathrm{S})+$ Predicate $(\mathrm{P})+\operatorname{Object}(\mathrm{O})$. Meanwhile, the TL sentence is formed with Subject $(\mathrm{S})+$ Predicate $(\mathrm{P})+$ Adverbial $(\mathrm{A})$. Therefore, there is a structure shift in this translation because TL sentence contains different elements with SL sentence. This structure shift can be considered an optional translation shift, because the TL structure can actually follow SL structure. 
In term of accuracy, although barely, the translation above is considered as an accurate translation. It is because, eventhough the message in SL is still transfered to TL, the translation is not so clear and there are some re-construction that need to be done. For instance, in the phrase The second cycle teacher teaching activity, the translator should have put the word of between the words cycle and teacher. Another case, the dependent clause while the percentage was not reached by $7,14 \%$ or 1 aspects is somehow unclear. It should have been while the percentage that was not reached was 7,14\% or 1 aspect.

\begin{tabular}{|c|c|}
\hline Source Language & Target Language \\
\hline $\begin{array}{l}\text { Hasil tentang kemampuan motorik } \\
\text { halus anak melalui kegiatan } \\
\text { Mewarnai, Menggunting dan } \\
\text { Menempel }(3 M) \text { menunjukkan } \\
\text { bahwa terdapat peningkatan. }\end{array}$ & $\begin{array}{l}\text { The result of the research about the } \\
\text { children fine motor ability through } \\
\text { coloring, cutting and pasting ( } 3 \text { kind } \\
\text { activities) showed the achieved, it } \\
\text { could be prove at the result of pre- } \\
\text { observation before and after action. }\end{array}$ \\
\hline
\end{tabular}

By comparing the SL-TL pair, it is noticed that the elements of both sentences do not formally correspond. The SL sentence is formed with elements $\mathrm{S}+\mathrm{P}+\mathrm{O}$. Meanwhile, the TL sentence is formed with elements $\mathrm{S}+\mathrm{P}+\mathrm{C}+\mathrm{A}$. Therefore, there is a structure shift in this translation because SL and TL sentences contain different set of elements. This structure shift can be considered an optional translation shift, because the TL structure can actually follow SL structure.

Regarding the accuracy of the above translation, it can be said that the translation is inaccurate. This conclusion is drawn by the fact that the SL message is not accurately transferred into TL and, not to mention, some grammatical errors in the TL. Moreover, the translator also put unnecessary additional substraction message in TL. It is found in the clause it could be prove at the result of preobservation before and after action. Consequently, this leads to inaccurate translation. 


\begin{tabular}{|l|l|}
\hline \multicolumn{1}{|c|}{ Source Language } & \multicolumn{1}{c|}{ Target Language } \\
\hline $\begin{array}{l}\text { Pada siklus II, diperoleh persentase } \\
\text { sebesar } 87 \% \text { atau } 13 \text { orang dari 15 } \\
\text { anak. }\end{array}$ & $\begin{array}{l}\text { Cycle II obtained the } \\
\text { percentage of 87\% or 13 of 15 } \\
\text { children }\end{array}$ \\
\hline
\end{tabular}

In the above SL-TL pair, it is noticed that the elements of both sentences do not formally correspond. The SL sentence is formed with $\mathrm{A}+\mathrm{P}+\mathrm{C}$. Meanwhile, the TL sentence is formed with $\mathrm{S}+\mathrm{P}+\mathrm{O}$. Therefore, there is structure shift in this translation because SL and TL sentences contain different elements. This structure shift can be considered as a mandatory translation shift. It is because if the translator follows the SL structure, the TL sentence will not be acceptable.

The above translation is one translation that can be considered as a very accurate translation. First of all, the SL message is accurately transferred. There is also no addition or subtraction message in target language (TL). Ultimately, The translation is clear and easy to understand with acceptable TL grammatical rules and reconstruction is not needed. In short, it meets the necessary condition of being very accurate translation.

\section{Discussion}

This study attempted to trace the occurrence of structure shift which, based on Catford (1965: 77), is the most frequent translation shift. The finding of the study simply shows that structure shifts do occur in the Indonesian-English translation of thesis abstract. Based on the findings, most of these structure shifts occur optionally. It means most of the time that the translators make their own choice to do shifting and is not dictated by the language system. However, we need to extremely focus on the accuracy of the translation.

This study considers the need to highlight the accuracy of translation found after the analysis of the data. In this study, there are 10 data of structure shift. Based on these data, 4 of them are considered as inaccurate translation; 5 are considered as accurate translation; and only 1 is considered as a very accurate translation. Indeed, there are $60 \%$ accurate translation found in the data which is more than the inaccurate translation. However, the $40 \%$ for the inaccurate 
translation is still overwhelming. This number seems to say that structure shifts make bad translation.

The data analysis revealed that these inaccurate translations occurred because of the bad construction of the TL sentences. All of them have some grammatical errors, misplacing of words, and misuse of words, that consequently make the transfer of SL message inaccurate. Therefore, the structure shift can not be blamed for these poor and inaccurate translation.

Actually, a structure shift, or a translation shift in general, can help translators to better translate a text. However, simply changing the structure does not guarantee the accuracy of the translation. In this case, the role of translation is very essential. A translator has to have a proper knowledge about SL and TL language systems. So, he/she will be able to avoid a poorly constructed TL sentence that leads to inaccurate translation. By having proper knowledge of SL and TL language systems, a translator will of course have more options in translating. He/she can use shifting technique without making mistake in constructing TL sentence.

\section{Conclusion}

This research aims to find out and describe the structure shift in the Indonesian-English translation of thesis abstracts at Teacher Training and Education Faculty of Halu Oleo University. The analysis of the category shift is based on the theory of Catford (1965). After describing an overview about the structure shifts in the translation of the thesis abstracts selected as the corpus of this study, some conclusions are drawn as the following:

1. Structure shifts do exist in the translation of thesis abstract at Halu Oleo University.

2. The strucutre shift in the translation of thesis abstracts can either be mandatorily or optionally.

3. The translator"s comprehension about the TL language system is highly required in order to produce an accurate translation. 
The researcher would like to suggest to practitioners of translation especially for those who are still new in this field that the missing of formal correspondence in translation is not necessarily resulting in bad translation. In fact, in many occasions, it is required to be done. The important thing is that shifting in translation has to be committed in proper way so that the accurate translation can be obtained.

It is also higly recommended that the translation shift to be selected and discussed as one of the topics in translation class. So, students will have more ammunition when doing translation. This will at least help them to become better translator in the future.

For any other student researcher who is interrested in investigating the translation shift, it is a good idea to focus the study to other kind of texts. It is also best to direct the study into translation class.

\section{References}

Al-Zoubi, M. Q., and Al-Hassnawi, A. R. (2001). Constructing a model for shift analysis in translation. Translation Journal, 5(4), 1-37. Retrieved from http://translationjournal.net/journal/18theory.htm last update on $20 / 11 / 2016$

Catford, J. C. (1965). A Linguistic Theory of Translation (Vol. 31). London: Oxford University Press.

Cyrus, Lea. (2006). Building a Resource for Studying Translation Shifts. In: Proceedings of the Fifth International Conference on Linguistic Resources and Evaluation (LREC-2006). Genoa, Italy. pp. 1240-1245.

Cyrus, Lea. (2009). Old Concepts, New Ideas: Approaches to Translation Shifts. MonTI I

DeCapua, Andrea. (2008). Grammar for Teachers: A Guide to American English for Native and Non-Native Speakers. New York: Springer.

Farrokh, Parisa. (2011). The Equivalence and Shift in the Persian Translation of English Complex Sentence with WH-Subordinate Clauses. In Canadian Center of Science and Education Journal vol. 1 no. 2, pp 74-81 December 2011. Retrieved from http://www.ccsenet.org/journal/ index.php/index/search/results. Last updated on 20/10/2016 10:12:11 
Foster, Danny. (2016). What Really is Translation Accuracy?. Retrieved from http://wordalive.wycliffe.ca/stories/b-i-what-really-is-translation-accuracyi-b last update on 20/11/2017.

Herman. (2014). Category Shifts In the English Translation of Harry Potter and the Philosopher's Stone Movie Subtitle into Indonesia (An Applied Linguistics Study). IOSR Journal Of Humanities And Social Science (IOSR-JHSS) Volume 19, Issue 12, Ver. V (Dec. 2014), PP 31-38.

Hosseini-Maasoum, S. M., and Shahbaiki, A. (2013). Translation shifts in the persian translation of a tale of two cities by Charles Dickens. Academic Journal of Interdisciplinary Studies, 2(1), 391.

Kies, Daniel. (2005). Writing an Abstract. Retrieved from http://papyr.com/hypertextbooks/comp2/abstract.htm Last update on 20/11/2016

Machali, R. (2000). Pedoman Bagi Penerjemah. Jakrat: PT. Grasindo.

Nida, Eugene and Taber, Charles R. (1982). The Theory and Practice of Translation. Leiden: E. J. Brill.

Ordudari, Mahmoud. (2007). "Translation Procedures, Strategies and Method". Translation Journal. Volume 11, No. 3 July 2007. Retrieved fromhttp://translationjournal.net/journal/41culture.htm last updated on 20/11/2016 09:58:34.

Susana. (n.d.). The Analysis of Structure Shift in Translating Locative Prepositional Phrase Into Indonesian. Retrieved from https://media.neliti.com/media/publications/229774-the-analysis-ofstructure-shift-in-trans-ae088c37.pdf

Yin, Robert K. (2011). Qualitative Research from Start to Finish. London and New York: The Guilford Press. 